\title{
Industrial Engineering, Operations Management and Sustainability: Overview
}

\author{
Carla Gonçalves Machado \\ Pamela Mocelin Manfrin \\ Pontifical Catholic University of Paraná (PUCPR), Curitiba, PR, Brazil \\ Edson Pinheiro de Lima \\ Sergio Eduardo Gouvêa da Costa \\ Pontifical Catholic University of Paraná (PUCPR), Curitiba, PR, Brazil \\ Federal University of Technology - Parana (UTFPR), Curitiba, PR, Brazil
}

\begin{abstract}
Several authors have been dedicating their efforts to understand and map topics and themes in the field of Industrial Engineering (IE), particularly those related to Operations Management $(\mathrm{OM})$, with special regard to sustainability. Bibliometric analyses were performed by using information collected from 495 selected papers in nine OM-related international databases, based on the keywords "Sustainability" and "Operations Management". Results pointed out to the evolution of the subject over the past two decades, the relationship among authors in their network of research, its effect on productivity and the related research topics. The results also indicated the main developing issues, authors, institutions and journals most devoted to the subject and the contribution of the study by establishing $\mathrm{OM}$ as a discipline in Industrial Engineering. Finally, the current paper will offer an overview of the trends for further research on sustainability into the OM field.
\end{abstract}

Keywords: Industrial engineering, Operations management, Sustainability, Bibliometric analysis.

\section{Introdution}

Traditionally, Operations Management (OM) is a study field in the business school organizations. In Industrial Engineering (IE), the topics defined by this study field are not precisely grouped. However, there has been a recent effort in order to organize them by the 'Engineering Management' label. Some Engineering School departments are being named 'Engineering Management Department', 'Industrial Engineering and Management' or even 'Industrial Engineering and Operations Management'. It could be assumed that the Industrial Engineering knowledge domain contains the topics that define Operations Management.

Over the last years, several studies have mapped the intellectual structure and defined the field of Operations Management (OM) into the Industrial Engineering area. Sprague (2007) found a strong interface between 'business' and 'engineering' disciplines when analyzing the origin of the OM discipline in business schools. The 
author pointed out that this interface made difficult the establishment of boundaries for researching OM. It could be assumed that this research is also positioned in the Industrial Engineering area.

Slack $(2005$, p. 323$)$ also conducted a study in order to identify OM borders and, more specifically, to highlight that operations strategy has not reached its full potential yet. That is, some opportunities still exist, generating content and process models that could cover all sustainability dimensions. This strategic approach for understanding operations contribution is a typical topic that could be studied in the business school OM groups or in the EM group from the IE department into an engineering school.

Based on the scientific production published by the International Journal of Operations \& Production Management (IJOPM) between 1994 and 1997, Pilkington and Liston-Heyes (1999) indicated some difficulties and their causes in the recognition of the $\mathrm{OM}$ as a legitimate academic discipline, emphasizing the need to differentiate the OM from Operations Research (OR) and Management System (MS).

Pilkington and Fitzgerald (2006) extended the analysis on the IJOPM production between 1994 and 2003, mapping the social relations established in the study communities and their research topics. Once more, the authors indicated the concern to define the $\mathrm{OM}$ as a discipline and the requirement to establish the knowledge generated in the field as a practical tool to determine its relationship with other management areas. Among the major OM-related topics, the authors presented 'manufacturing strategy' and 'resource-based view'. Based on the scope of including sustainability, it was identified the emergence of the 'sustainable resource view' topic in papers from 1995, with Hart (1995), and Porter and Van der Linde (1995) showing the trend of including sustainability in OM studies.

Bayraktar et al. (2007) also conducted a study dedicated to the OM evolution through the themes and characteristics of research communities in Europe and North America, noting that the field has its core in the design and management of the transformation processes that create value for the organizations and the society, thus revealing the ability of the OM in the study of the processes and more sustainable technologies.

Expanding on the research, Pilkington and Meredith (2009) analyzed the academic production from 1980 to 2006 and dedicated efforts to map the intellectual structure of the OM, by checking the need for further strategic issues, both of integrated and macro nature. Also, the analysis covered the IJOPM content of the Journal of Operations Management (JOM) and Production Operations and Management (POM). Through the analysis method of the social networks, the authors presented a map of the clusters formed by researchers, showing how the networks have changed over the years, thus concluding that the OM field is dynamic, with significant changes and with theories taken from other fields, leading to the development of new research methods.

Taylor and Taylor (2009) also gave their contribution to the field study, by verifying IJOPM papers published between 2004 and 2009; indicating the commonly used research methods (e.g. survey and case studies), the main topics (e.g. supply chain management and operations strategy) and some other information for OM field 
researchers, as Bayraktar et al. (2007), but more emphatically, the authors analyzed sustainability as a potential topic in the OM research.

Other noteworthy studies have also leant over the OM field, such as Sower et al. (1997), Sprague (2007) and Seuring and Muller (2008). Most of the studies cited - devoted to map the OM intellectual structure and trends - were performed with the support of bibliometric data. It reaffirms McIntire's concept (2006), stating that the development of a certain field can be followed by means of published academic production, using bibliometric data, which can be extracted as author, title, citation, date, keywords etc.

This paper presents some initial results obtained from ongoing literature review for a doctoral thesis and intends to contribute with the OM studies. It informs on the integration of sustainability concepts with the OM field, taking as a premise that this sub-theme is emerging and relevant according to the number of publications in the area.

$\mathrm{OM}$ research in sustainability is a growing issue and it is generating new theories and models for OM practice. First, sustainability could not be achieved by a single firm's action. Research has shown that for sustainability to be truly effective, entire supply chains, not just individual partners, must operate in a sustainable manner (Carter and Rogers, 2008; Kleindorfer et al., 2005). Establishing the way aspects concerning the sustainable development have been worked out according to the operations has become relevant to the researchers, because they provide some indication on the main developing issues, authors and schools devoted to the topic, main journals and, especially, the contribution of the studies with the establishment of the OM as a discipline in Industrial Engineering.

As time parameters, papers published from 1995 until the first half of 2011 were selected out of nine OM-related databases, and the keywords 'sustainability' and 'operations management' were chosen as the metasearch criteria. They represent the study contribution to the OM field evolution, even though applying only to the sample of 495 papers.

The structure of this paper covers the literature review from the research undertaken, the methodology defining the basis for papers and methods for analysis, the results obtained from bibliometric analysis/descriptive statistics and respective considerations. At a second phase, statistical tests were selected in order to complement and validate some bibliometric analyses.

\section{Theoretical Background}

The World Commission on Environment and Development (WCED, 1987, p. 37) report offers the most widespread definition of sustainable development: "[...] meets present needs without compromising the ability of future generations to meet their own needs".

The limitation of the planet's natural resources to supply the high industrial demand, the excessive consumption and the increase in world population are rapidly promoting resource depletion and environmental degradation, reflecting an unsustainable growth model. The impacts are being felt faster than the first predictions. According to Almeida (2007), it was stated that, out of the 24 ecosystem services assessed by 
the Millennium Ecosystem Assessment (MEA), related to human survival, $60 \%$ are in accelerated degradation stage.

It is worth mentioning that globalization also encouraged discussions on sustainability, creating new contexts for the OM strategies. Corroborating with the aim of this study, it is shown below Taylor and Taylor's statement (2009) on the inclusion of sustainability in the OM:

We have commented upon potential new OM research topics including sustainability, the role and significance of HRM in operations servitisation and applications of OM in new contexts, such as the not-for-profit sector. We are confident that operations management will continue to be relevant for the problems and challenges of tomorrow's world (TAYLOR; TAYLOR, 2009, p. 1338).

Taking the studies above as a reference, sustainability is now part of the emerging sub-themes related to the OM evolution, indicating the formation of a community dedicated to study the application of concepts linked to the sustainable development of production systems and other traditional areas of the OM field.

Westkamper et al. (2000) state that in terms of sustainable development, the task of Production Engineering is necessary to encourage the industrialization process with a high level of automation and production technologies.

\section{Bibliometric Studies in Operations Management}

The set of bibliometric data extracted from an article grouping made possible the evaluation of the stage of evolution of a research field, assisted in the finding of research themes and relationships among researchers, as well as the formation of communities, and finally allowed for finding gaps in research and/or trends (Powell et al., 2005; White et al., 2004).

The use of bibliometric methods enabled the assessment of the scientific contributions in specific settings and behavior developed in the social networks created by the authors. The information shared in one group tends to be validated according to its replications and, through the citations, the articles form a knowledge network (Pinheiro and Silva, 2008).

Several studies were conducted to map the field studies of the $\mathrm{OM}$ and its evolution, many of them were directed by the pursuit of the most influential authors and research topics and methodologies with the highest rate of occurrences. This study highlights just a few of those already mentioned in the introduction, thus explicitly introducing the sustainability theme in the OM field.

Pilkington and Fitzgerald (2006), with the techniques of statistical and bibliometric analysis in 829 articles between 1994 and 2003, extracted a set of information indicating a central field of study focused on manufacturing strategy and a group of researchers forming a community around this theme, including Hayes and Wheelwright (1984) and Skinner $(1969,1974)$. According to the authors, the entry of the new theme, sustainable resource view of the firm "[...] is a new entrant to the 
significant sub-field, and again revels to the openness of the OM emerging debates in the subject of strategic management" (Pilkington; Fitzgerald, 2006, p. 1266).

Analyzing a longer period, 1980-2006, Pilkington and Meredith (2009) have collected articles from three OM-related journals and traced the evolution of the field over the decades. Again, 'Manufacturing Strategy' appears as the most recurrent theme, along with 'Quality and Metrics' and 'Statistical Methods'. However, the authors pointed out that the theme of 'Supply Chain and Quality' has been gaining ground over the years and the increased interest in statistical and qualitative methods showed the trend of increasing the accuracy of the results and empirical research.

Bayraktar et al. (2007) had pointed out the tendency for studies in supply chain, and according to the authors, a good supply chain management provides competitive advantage to the company's global business environment.

Seuring and Muller (2008) conducted a literature review from 191 papers published from 1994 and 2007. They pointed out two mainly themes: the focus on the supplier management to improve performance and reduce risk; and supply chain management for more sustainable products.

In the study by Taylor and Taylor (2009), the 'supply chain management' theme appears as the main topic of research articles published by IJOPM between 2004 and 2009, thus confirming the trend indicated in the study by Bayraktar et al. (2007) and Seuring and Muller (2008).

As Bayraktar et al. (2007), but more emphatically, Taylor and Taylor (2009) check for the presence of the topic of sustainability as a potential topic in the OM field.

\section{Operations Management and Sustainability}

Models of operations management have been facing the challenge of inserting sustainability awareness into their practices. Some researchers and practitioners have focused their decision models based on the concept of the Triple Bottom Line (TBL), both for new research and for the design of processes and daily practices (Elkington, 1997; Wilkinson et al., 2001; Porter and Kramer, 2006; Hutchins and Sutherland, 2008; Ueda et al., 2009).

According to Kleindorfer et al. (2005) Sustainable Management of Operations is defined as the sum of skills and concepts which allows companies for structuring and managing their business processes in order to achieve competitive returns on their capital assets, without compromising the legitimate needs of internal and external stakeholders, taking into account the impact of operations on people and environment.

Bayraktar et al. (2007) emphasize that the models of future operations will be directed by management measures, criteria and environmental policies, responsiveness and sustainability by the companies towards the future as well as the efficient use of scarce resources.

Pinheiro de Lima et al. (2008, p. 267) then complemented this view by stating that the new strategic vision of the production is $[. .$.$] the interaction environment$ within the company and its essence and that is the great challenge of modern business". The researchers also cited other research groups that have devoted to the sustainable 
management study in various areas of the OM, such as Kleindorfer et al. (2005), Gold et al. (2010), Platts (2007) and Seliger (2007).

The studies directed to the OM intellectual mapping show the field movement towards more tactic issues and identify that, until 2009, the main topics comprehended the areas of operations strategy, supply chain management, performance management, performance measurement and service operations.

Ueda et al. (2009) highlight the importance of an appropriate approach for sustainability issues in designing, implementing and running enterprises systems. Models should be developed and tested at the level of operations function and the entire system of value chain.

Pitelis and Vasilaros (2010) define a process for creating sustainable value by its integrative capabilities in running economic, environment and social recommendations.

Talbot and Venkataraman (2011) argue that sustainability is an enterprise feature that should be integrated to design activities. Van Bommel (2011) highlights the importance of innovation in developing OM sustainable competences as the present production systems are reaching their improvements limits.

This brief review indicates an evolution in sustainability studies in the OM field. According to Leidersdorff (2007), it is possible to observe the development of a specific study field by the scientific production attributed to it.

The use of bibliometrics allows for the assessment of the scientific contribution in specific scenarios and the behavior developed in social networks created by the authors. The information shared in a group tends to be validated as it is replicated. Through quotations, the papers converge into a knowledge network (Machado-da-Silva et al., 2006; Pinheiro and Silva, 2008).

\section{Research Methodology and Data Collection}

This paper is a documental and exploratory research. The analyses cannot be taken as complete interpretations, due to the difficulties in capturing, quantifying and visualizing all the collected data. In order to diminish the impact of the limitations, the processes and criteria defined to the collection were strictly followed, as well as the established methodology. According to Garfield (1997) the inference on the first author alone may incur in some deficiency. Therefore, in this study, all authors were regarded as so important as the first author.

It is relevant to clarify that this study does not regard the limitations of the analysis on quotation and co-quotation presented by Taylor and Taylor (2009), presenting the favoring occurred when some author quoted another authors motivated by the prestige of more experienced researchers, with longer careers, controversial articles and other reasons, which make the quotation be less valuable.

The steps and results comprising the development of the articles selection are described in Table 1.

For this study, it is important to highlight some points. The choice of databases was performed in an initial search based on the relevance for the OM field and the keywords 'sustainability' and 'operations management'. After the first general selection of papers, analyses of significance and content were performed by reading the abstracts and keywords, and the result of this analysis showed 1995 as the year of 
Table 1. Steps for collecting and analyzing data.

\begin{tabular}{|c|c|c|}
\hline Stage & Actions & Results \\
\hline \multirow{5}{*}{$\begin{array}{c}\text { Data } \\
\text { collection }\end{array}$} & $\begin{array}{l}\text { General search on the ISI Thompson, Scopus and } \\
\text { "CAPES journal site" bases, in order to select } \\
\text { academic bases connected to the OM. }\end{array}$ & $\begin{array}{l}\text { Academic Search Premier/ } \\
\text { EBSCO, Emerald, IEEE } \\
\text { Xplore, Oxford Journals, } \\
\text { Science Direct, Springer } \\
\text { Verlag, Taylor and Francis and } \\
\text { Wiley Interscience, Scielo. }\end{array}$ \\
\hline & $\begin{array}{l}\text { First filtering of papers by keywords: } \\
\text { "sustainability" and "operations management". }\end{array}$ & Circa 1,000 selected papers. \\
\hline & $\begin{array}{l}\text { Second filtering of papers by relevance, content and } \\
\text { interactions with issues connected to the keywords. }\end{array}$ & $\begin{array}{l}495 \text { selected papers with } 908 \\
\text { authors. }\end{array}$ \\
\hline & $\begin{array}{c}\text { Author selection based on the quantity of } \\
\text { authorships (three, at least) and its representation } \\
\text { (Pareto principle) in the sample (supported by } \\
\text { Mendeley App. and extracted / organized manually } \\
\text { in EXCEL }{ }^{\circledR} \text { worksheets) (Mendeley Supporting } \\
\text { Team, 2011). }\end{array}$ & $\begin{array}{l}47 \text { authors extracted to the } \\
\text { network analysis and statistical } \\
\text { tests, responsible for } 18 \% \text { of } \\
\text { the total papers production } \\
\text { (208 papers). }\end{array}$ \\
\hline & $\begin{array}{l}\text { Organization and refining (repeated items, } \\
\text { synonyms and others not related to this study) of } \\
\text { keywords from } 495 \text { selected papers (performed } \\
\text { with the support from Mendeley App. and extracted } \\
\text { / organized manually in EXCEL }{ }^{\circledR} \text { worksheets) } \\
\quad \text { (Mendeley Supporting Team, 2011) }\end{array}$ & $\begin{array}{c}1,713 \text { keywords }- \text { after } \\
\text { refining, sample of } 752 \text { words } \\
\text { organized according to the total } \\
\text { representativeness. }\end{array}$ \\
\hline $\begin{array}{c}\text { Social } \\
\text { Network } \\
\text { analysis }\end{array}$ & $\begin{array}{l}\text { Generation of relationship matrices, turned into } \\
\text { square matrices. Making of social network graphs } \\
\text { (UCINET Software and Netdraw app.). }\end{array}$ & $\begin{array}{l}\text { Extraction of centrality } \\
\text { measures and making of } \\
\text { author network graph with } \\
\text { core-periphery parameter and } \\
\text { keyword network graph. }\end{array}$ \\
\hline $\begin{array}{l}\text { Statistical } \\
\text { tests }\end{array}$ & $\begin{array}{l}\text { Selection and performance of tests by using } \\
\text { multivariate data analysis methods, suitable to the } \\
\text { sample size (SPSS } 17 \text { software). }\end{array}$ & $\begin{array}{l}\text { (1) normality tests of the } \\
\text { centrality and productivity } \\
\text { measures of the authors; } \\
\text { (2) correlation test between } \\
\text { the centrality and productivity } \\
\text { measures of the authors; } \\
\text { (3) difference test of medians } \\
\text { between network core- } \\
\text { periphery. }\end{array}$ \\
\hline
\end{tabular}

the emergence of relevant studies in the context studies (Environmental management and its impact on the operations function, by Mahesh C. Gupta).

The selection of the network measures was based on Hanneman and Riddle (2011), Garfield (1997), Burt (1992), and Kleinberg et al. (2008) studies. The selected network measures were:

- Degree - actors with a higher degree centrality measure have a greater number of connections and tend to be at a privileged position. Therefore, they tend to have a greater influence in the network; 
- Closeness - the shorter the distance of an actor from another actors, the more accessible he/she is to 'reference points', and those who have a more powerful representation;

- Betweenness - an actor/connector between two other network actors has a structurally more favored position, because if one actor wants to contact another, he/she has to do it through the connector;

- Effsize - the structural holes represent a gap between actors, that is, absence of relations in the social structure, thus inhibiting the information flow among the groups. Actors from both sides of a structural hole have access to diverse information flows, and the structural holes represent an opportunity for an actor to come up with new ideas, which may intermediate the information flow and control the projects coming from the union of opposite sides of the structural hole.

The statistical tests were selected according to the sample size and studies by Field (2009). In order to verify the data normality, the Kolmogorov-Smirnov (K-S) test was performed. Following that, the Spearman correlation test was applied, because it is the most suitable for small and non-normal (non-parametric) samples.

\section{Hypotheses}

Network studies help in the evaluation of several aspects: the development stage in a determined field, its core and peripheral topics, the relationship among the researchers, how communities are shaped, the relation of a certain topic with other study fields - where the main research centers are located -, the trends in development studies (Sengupta, 1992).

Based on theoretical references, it is supposed that the authors' productivity is related to the centrality measures obtained from network analysis, thus demonstrating that, in general, the privileged position in the network contributes to the author's productivity (H1). Then, it is supposed that the measures indicating some author's position in the network determine his/her location in the network core or periphery (H2), and that there are statistically significant differences between core and periphery network measures, thus showing that, in general, authors regarded as "central", by means of their relationships, may obtain more advantages than the peripheral authors (H3).

According to the hypothesis, it is assumed that central authors, found through social network analysis, have a greater influence on the studies of the field, including the direction of the main topics addressed by the field.

\section{Results and Discussion}

Based on the categorization and organization of information extracted from 495 papers, this study presented a general study on the sustainable management of operations, in order to examine opportunities for further research and trends among researchers. A first relevant piece of information is on the growth in the number of published articles on the subject discussed. It is possible to see continuous growth from 2008 to 2010 (Figure 1), when the number of publications represented approximately $49 \%$ of the total. 


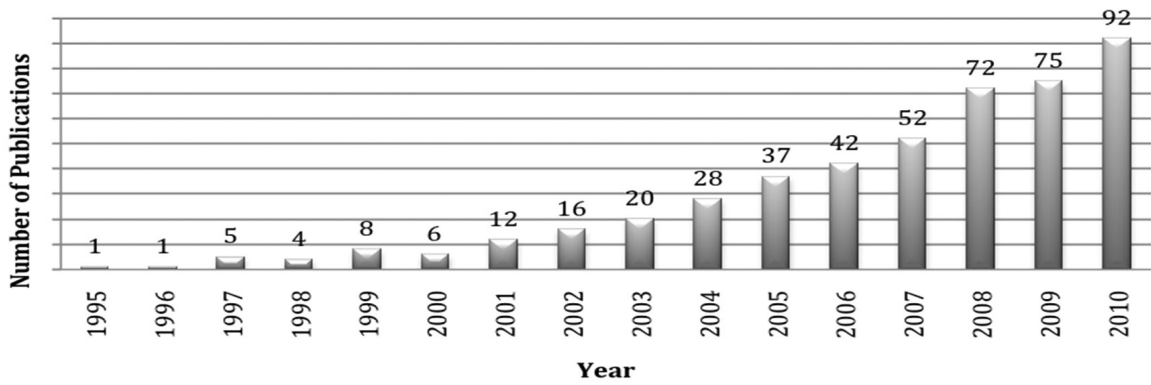

Figure 1. Evolution of the number of articles.

Data from 2011 indicate that the number of publications dropped (29 papers). This event may indicate that most authors have focused their efforts on specific topics related to the $\mathrm{OM}$ and sustainability, leaving behind the generality presented so far.

The selected papers are spread into 139 journals. The multidisciplinarity of the listed journals also ratifies the OM interface with the engineering and business disciplines, but also points out to the current trend that includes the sustainable perspective into several areas, thus enlarging the applicability and validation limits of this subtopic in scientific communities. Table 2 shows the top ten journals (by number of papers relating to the topic), and the distribution of papers per year of publication.

Journals listed in Table 2 can be considered representative of the OM field, because the set includes more than $40 \%$ of all productivity-related themes, which indicates their relevance in the diffusion of the topic, the inclination of the studies on sustainability in the OM and their preference by the author.

It appears that the majority of publications takes place in 2000 and at a greater number in 2008, indicating that the latest issue can be considered recent within the OM field and also showing a greater interest among journals, remarked with the occurrence of Special Issues on the subject, for example, special issue on "Sustainability and Supply Chain" (v.16, issue 12, 2009), Journal of Cleaner Production, and a special issue on "Sustainability" (v.21, issue 12, 2001) by the International Journal of Operations \& Production Management - IJOPM.

Looking from the point of view of frequent publications, the IJOPM is constant, regarding the publication period, being considered a precursor in publications relating to the OM and sustainability (1995). This fact may be relevant to the development of field studies, because according to Pilkington and Liston-Heyes (1999), some evidence of the difficulty in establishing the $\mathrm{OM}$ as a discipline is related to the low participation of researchers in journals devoted to it.

Out of the 927 compiled authors, samples were taken from 137 of them, responsible for the production of 397 papers ( $80 \%$ of the total), selected based on the production of at least two topic-related articles. The objective was the generation of a quotation square matrix, used by UCINET software and by the Netdraw application, in order to illustrate the network formed by the authors dedicated to the topic (Figure 2).

It is verified, according to the graph, the formation of a compact community, with some authors away from the network. According to the establishment of central 
Table 2. Main journals.

\begin{tabular}{|c|c|c|c|}
\hline Journal & $\begin{array}{c}\text { Papers published } \\
\text { in the perspective } \\
\text { of sustainability } \\
\text { and the } O M\end{array}$ & $\begin{array}{c}\% \text { in the } \\
\text { total of } \\
\text { productivity }\end{array}$ & $\begin{array}{c}\text { The year of publication } \\
\text { of the selected papers } \\
\text { (number per year) }\end{array}$ \\
\hline Journal of Cleaner Production & 58 & 12 & $\begin{array}{c}2001(2), 2003(1), 2004(1), \\
2005(2), 2006(7), 2007(3), \\
2008(17), 2009(9), 2010 \\
(14), 2011(2)\end{array}$ \\
\hline $\begin{array}{c}\text { International Journal of } \\
\text { Sustainability in Higher } \\
\text { Education }\end{array}$ & 27 & 5 & $\begin{array}{l}2000(1), 2002(2), 2003(1) \\
2004(2), 2005(5), 2006(4), \\
2008(3), 2009(2), 2010(2), \\
2011(5)\end{array}$ \\
\hline $\begin{array}{c}\text { International Journal of } \\
\text { Operations \& Production } \\
\text { Management }\end{array}$ & 26 & 5 & $\begin{array}{l}1995(1), 1996(1), 1998(1), \\
1999(1), 2000(4), 2001(5), \\
2002(1), 2003(1), 2004(1), \\
2005(2), 2006(2), 2007(2), \\
2008(1), 2009(1), 2010(1), \\
2011(1)\end{array}$ \\
\hline $\begin{array}{c}\text { Business Strategy and the } \\
\text { Environment }\end{array}$ & 25 & 5 & $\begin{array}{l}2004 \text { (2), } 2005 \text { (2), } 2007 \text { (4), } \\
2008(5), 2009 \text { (3), } 2010 \text { (7), } \\
2011(2)\end{array}$ \\
\hline $\begin{array}{l}\text { Supply Chain Management: } \\
\text { An International Journal }\end{array}$ & 14 & 3 & $\begin{array}{c}2005(1), 2006(1), 2009(9), \\
2010(3)\end{array}$ \\
\hline $\begin{array}{l}\text { Benchmarking: An } \\
\text { International Journal }\end{array}$ & 13 & 3 & $\begin{array}{c}2003(2), 2005(3), 2008(1), \\
2010(7)\end{array}$ \\
\hline $\begin{array}{c}\text { Corporate Social } \\
\text { Responsibility and } \\
\text { Environmental Management }\end{array}$ & 13 & 3 & $\begin{array}{c}2002(1), 2005(1), 2006(2), \\
2007(1), 2008(2), 2009(1), \\
2010(3), 2011(2)\end{array}$ \\
\hline $\begin{array}{c}\text { International Journal of } \\
\text { Physical Distribution \& } \\
\text { Logistics Management }\end{array}$ & 11 & 2 & $\begin{array}{c}2003(1), 2005(1), 2008(3) \\
2009(1), 2010(5)\end{array}$ \\
\hline $\begin{array}{l}\text { International Journal of } \\
\text { Production Economics }\end{array}$ & 11 & 2 & $\begin{array}{c}1999(1), 2007(1), 2008(6), \\
2009(1), 2010(2)\end{array}$ \\
\hline Ecological Economics & 9 & 2 & $\begin{array}{c}2002(1), 2004(1), 2008(2), \\
2009(4), 2010(1)\end{array}$ \\
\hline Total & 207 & 42 & --------------------------------- \\
\hline
\end{tabular}

authors in the network, a sample consisting of 47 authors was submitted to coreperiphery categorization by the Netdraw application, and centrality measures were then obtained. Nineteen authors were considered as central authors in the network (Figure 3).

According to Figure 3, it is verified a robust relationship among the majority of central authors (in grey) and their closeness. It can indicate that the research is more guided, in its majority, towards some common topics. Table 3 shows the productivity and network measures from 19 central authors. However, the statistical correlation tests were performed with the 47 selected authors. 


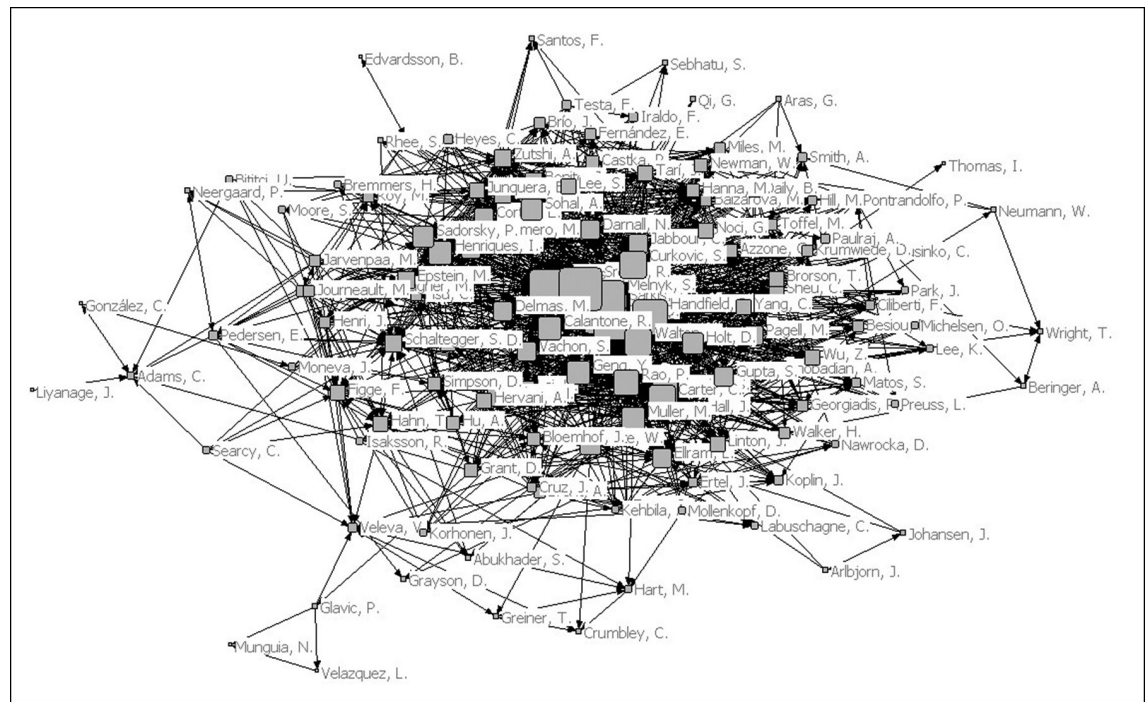

Figure 2. Social network formed by 137 authors.

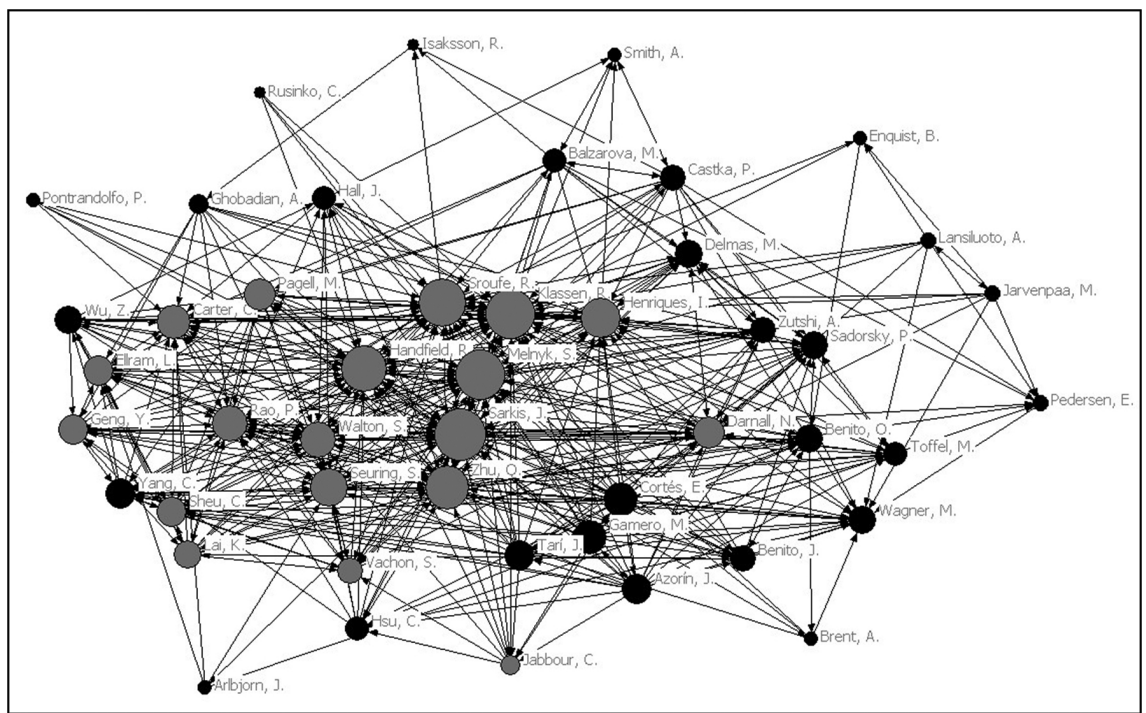

Figure 3. Author network: core-periphery.

Taking the authors Joseph Sarkis (CD 87) and Qinghua Zhu (CD 70) as examples, it is noted their closeness in the network and in this context, these two authors wrote ten papers together. This fact represents, respectively, about $50 \%$ and $80 \%$ of productivity of each author. However, some authors located in the periphery presented greater centrality measures than others from the core. One of the differential factors is the number of entries (represented by the arrows towards the nodes), indicating how often this author is referenced by others. 
Table 3. Core authors.

\begin{tabular}{|c|c|c|c|c|c|}
\hline Authors & Degree (CD) & Closeness & Betweenness & Effsize & Production \\
\hline Sarkis, J. & 87 & 88 & 8 & 27 & 19 \\
\hline Klassen, R. & 83 & 85 & 8 & 25 & 8 \\
\hline Melnyk, S. & 83 & 85 & 6 & 25 & 3 \\
\hline Sroufe, R. & 80 & 84 & 9 & 25 & 3 \\
\hline Handfield, R. & 74 & 79 & 3 & 21 & 6 \\
\hline Zhu, Q. & 70 & 77 & 3 & 20 & 12 \\
\hline Henriques, I. & 63 & 73 & 3 & 18 & 3 \\
\hline Seuring, S. & 59 & 71 & 2 & 16 & 8 \\
\hline Walton, S. & 57 & 70 & 1 & 14 & 4 \\
\hline Rao, P. & 57 & 70 & 1 & 14 & 4 \\
\hline Carter, C & 52 & 68 & 2 & 12 & 5 \\
\hline Darnall, N. & 48 & 66 & 1 & 13 & 4 \\
\hline Pagell, M. & 48 & 66 & 1 & 11 & 4 \\
\hline Ellram, L. & 46 & 65 & 1 & 10 & 3 \\
\hline Sheu, C. & 46 & 65 & 0 & 9 & 3 \\
\hline Geng, Y. & 43 & 64 & 0 & 9 & 4 \\
\hline Lai, K. & 39 & 61 & 0 & 9 & 5 \\
\hline Vachon, S. & 37 & 61 & 0 & 7 & 4 \\
\hline Jabbour, C. & 26 & 57 & 0 & 6 & 6 \\
\hline & & & & & \\
\hline
\end{tabular}

Using the same example presented before, the partnership between Joseph Sarkis and Qinghua Zhu is characterized by being international, and according to Glänzel (2001), international co-authorship is often cited more than purely domestic papers, highlighting the importance of establishing relationships with other authors in the production of scientific research.

It became significant for this study to analyze the origin of the authors, however it is not intended to actually consider whether international partnerships are most often cited, although it is believed so, aiming to map the origin of production on the theme. Further research may examine the partnerships according to Glänzel's concept (2001).

Based on international production criteria, the papers were categorized into three types: (a) International - foreigners and author partnership from different countries; (b) Brazil - only Brazilians authors; (c) Multinational - Brazilians authors with foreigners. A total of 482 papers was written by means of international collaboration, 12 by Brazilian researchers and only one published by multinational collaboration.

Due to the presence of Brazilian researchers, it became relevant to complement the information on the origin of the authors (considering all of them), in order to know the country (Table 4) and institutions (Table 5) that have a higher number of researchers contributing to the study field. 
Table 4. Main countries (by number of papers published in the specific thematic of OM and Sustainability).

\begin{tabular}{|c|c||c|c|}
\hline Countries & \# papers & Countries & \# papers \\
\hline 1. USA & 278 & 7. Italy & 45 \\
\hline 2. UK & 158 & 8. China & 40 \\
\hline 3. Spain & 96 & 9. The Netherlands & 40 \\
\hline 4. Canada & 73 & 10. Sweden & 36 \\
\hline 5. Germany & 52 & 11. New Zealand & 33 \\
\hline 6. Australia & 49 & 12. Brazil & 27 \\
\hline
\end{tabular}

Table 5. Institutions (by number of researchers dedicated to the theme).

\begin{tabular}{|c|c|c|}
\hline Institution / Country & \# researchers & $\begin{array}{c}\text { Main subthemes in OM and } \\
\text { Sustainability }\end{array}$ \\
\hline University of Alicante (Spain) & 22 & environmental management \\
\hline Clark University (USA) & 20 & $\begin{array}{l}\text { environmental management; green } \\
\text { supply chain management }\end{array}$ \\
\hline Dalian University of Technology (China) & 17 & green supply chain management \\
\hline Michigan State University (USA) & 15 & $\begin{array}{l}\text { green supply chain management; } \\
\text { environmental management; supply } \\
\text { chain management; design for } \\
\text { environment }\end{array}$ \\
\hline University of Strathclyde (UK) & 15 & $\begin{array}{l}\text { CSR, performance measures, } \\
\text { operations management }\end{array}$ \\
\hline Erasmus University (The Netherlands) & 13 & $\begin{array}{l}\text { sustainable supply chain, } \\
\text { environmental management, supply } \\
\text { chain management }\end{array}$ \\
\hline University of California (USA) & 12 & $\begin{array}{l}\text { environmental management, reverse } \\
\text { logistics }\end{array}$ \\
\hline University of Sao Paulo (Brazil) & 11 & environmental management \\
\hline Lund University (Sweden) & 10 & $\begin{array}{l}\text { environmental management; supply } \\
\text { chain management }\end{array}$ \\
\hline Universidad de Oviedo (Spain) & 10 & environmental management \\
\hline University of Tennessee (USA) & 10 & supply chain management \\
\hline Wageningen University (The Netherlands) & 10 & $\begin{array}{l}\text { environmental management; supply } \\
\text { chain management }\end{array}$ \\
\hline
\end{tabular}

Looking at the representativeness of Brazil in the evolution of this research field, the country occupies the 12th position. Analyzing the 20 Brazilian authors, the University of São Paulo has a significant group of researchers (11), devoted to the issues of 'environmental management' and 'social dimension' in the OM. Authors in other Brazilian universities were also considered, such as University of Rio Grande do Sul (UFRGS), Federal University of São Carlos (UFSCAR), São Paulo State University 
(UNESP), Federal University of Espírito Santo (UFES) and the Federal University of Viçosa (UFV).

According to the first results, the evolution of the published papers indicates that the increase in the period can be mainly attributed to the evolution of discussions on environmental management systems, supply chain management and corporate social responsibility, in the context of sustainability. A quantitative keyword analysis points out these inferences (Table 6).

Analyzing the set of papers, it is possible to see a relationship between the words presented in Table 2, where 'sustainable development' is more often associated with 'environmental management'; 'supply chain management' is found associated in a balanced way with the words 'environmental management' and 'corporate social responsibility'; 'sustainability' and 'corporate social responsibility', both linked more often to 'supply chain management'.

In constructing keyword matrix ( $44 \times 44)$, a minimum of 06 (six) occurrences was defined as a criterion for selection. The final keyword matrix gave rise to the illustrated network in Figure 4.

Table 6. Main keywords (extracted by selected papers).

\begin{tabular}{|c|c|}
\hline Keywords & \# occurrences \\
\hline Sustainable Development & 82 \\
\hline Environmental Management & 73 \\
\hline Supply Chain Management & 61 \\
\hline Sustainability & 41 \\
\hline Corporate Social Responsibility & 38 \\
\hline
\end{tabular}

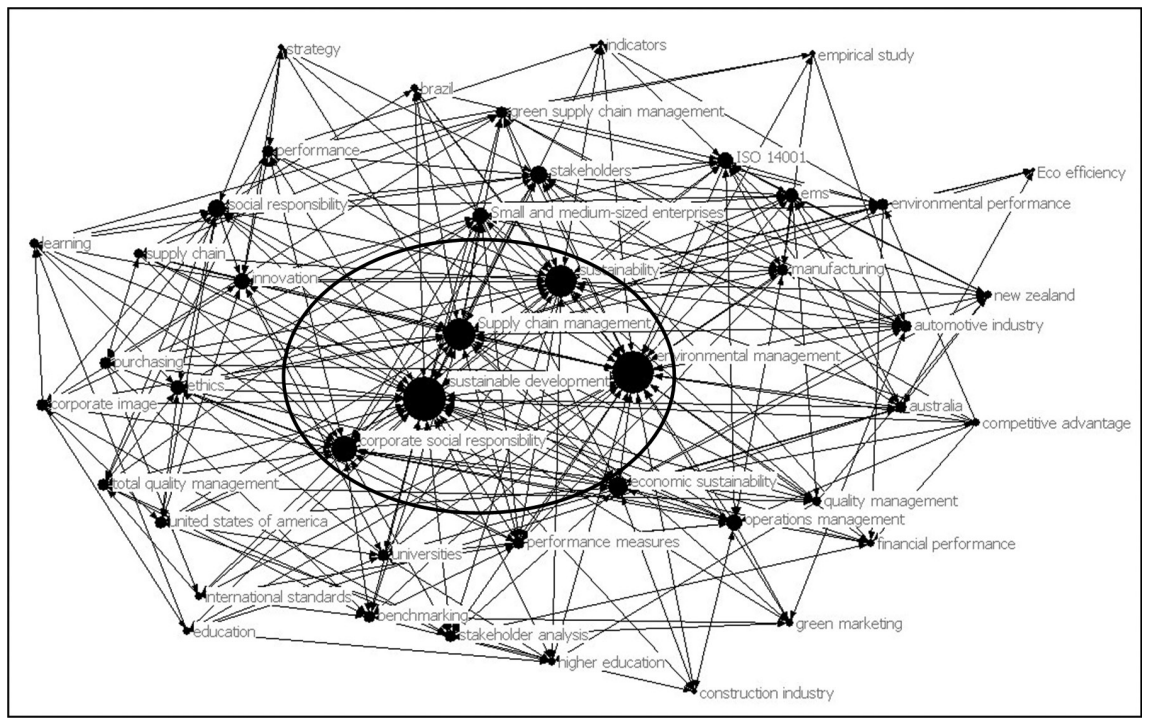

Figure 4. Relationship network among the main keywords. 
Visually, it is noted a central set of keywords, formed by "sustainable development" (CD 84); "environmental management" (CD 81); "sustainability" (CD 60); "supply chain management" (CD 60) and "corporate social responsibility" (CD 51 ). This word set indicates the most discussed or relevant research topics to the field. Circa 514 words were quoted only once and, according to Chuang et al. (2007), they may indicate a research continuity gap and disparity from the main study focus.

These results corroborate the studies of Taylor and Taylor (2009) on the strength of the supply chain studies in the OM and also with those of Seuring and Muller (2008), in which authors performed a literature review on sustainable supply chain management. According to Seuring and Miller (2008), the environmental dimension is present in more articles on sustainable supply chain, driven primarily by strong global pressure characterized by legal demands / regulation, customer demands and response to stakeholders. There are also some theories that have been linked to the study of sustainability in the OM, such as the Life Cycle Assessment (LCA), Sustainable Manufacturing, Corporate Social Responsibility (CSR) and Environmental Management, validating the results of Pilkington and Meredith (2009), thus concluding that the OM field is a dynamic field which uses theories from other fields, leading to new research methods.

Analyzing the keywords in the areas of interest and the statements of the authors (Table 7), the direction of the subjects becomes remarkable and, especially, a tendency to include the principles of sustainability in OM models that have previously been defined by the authors themselves or by the OM field - as the main research themes listed by Taylor and Taylor (2009) - in order to adapt them into the new sustainable development scenario.

The measures extracted from the network analysis of the 47 selected authors, adding each one's productivity to these data, were submitted to statistical tests, so that the hypotheses could be validated. Taking into account the normality test results (Degree 0.820**; Closeness 0.333**; Betweenness 0.001*; Effsize 0.309**; Productivity $0.000 *)$, it is verified the non-normal distribution of the data $(* \mathrm{p}<0.05$ - non-normal distribution $/ * * p>0.05$ normal distribution) and one of the causes of the non-normality can be attributed to the sample size (FIELD, 2009).

In the correlation analyses (Table 8), a significance value of $(\mathrm{p}<0.05)$ indicates a significant relationship among the variables and it can be either positive or negative (FIELD, 2009). In the sample, all variables are correlated in a significantly positive way (correlation coefficient positive).

From the correlation test result, it becomes relevant to validate the coreperiphery classification, thus verifying if there are statistically significant differences among the groups, which interfere with the productivity (Tables 9 and 10). The MannWhitney test is used to compare two situations when different groups take part in each condition (FIELD, 2009).

This result $(\mathrm{p}<0.05)$ pointed out that the network core-periphery classification is a good discriminant for centrality measures, because the groups present different measures (Mean Rank), thus validating the Core-Periphery relational configuration.

Based on the test results, all the hypotheses presented were validated. It was verified that the authors' productivity is positively correlated to the network relationship 


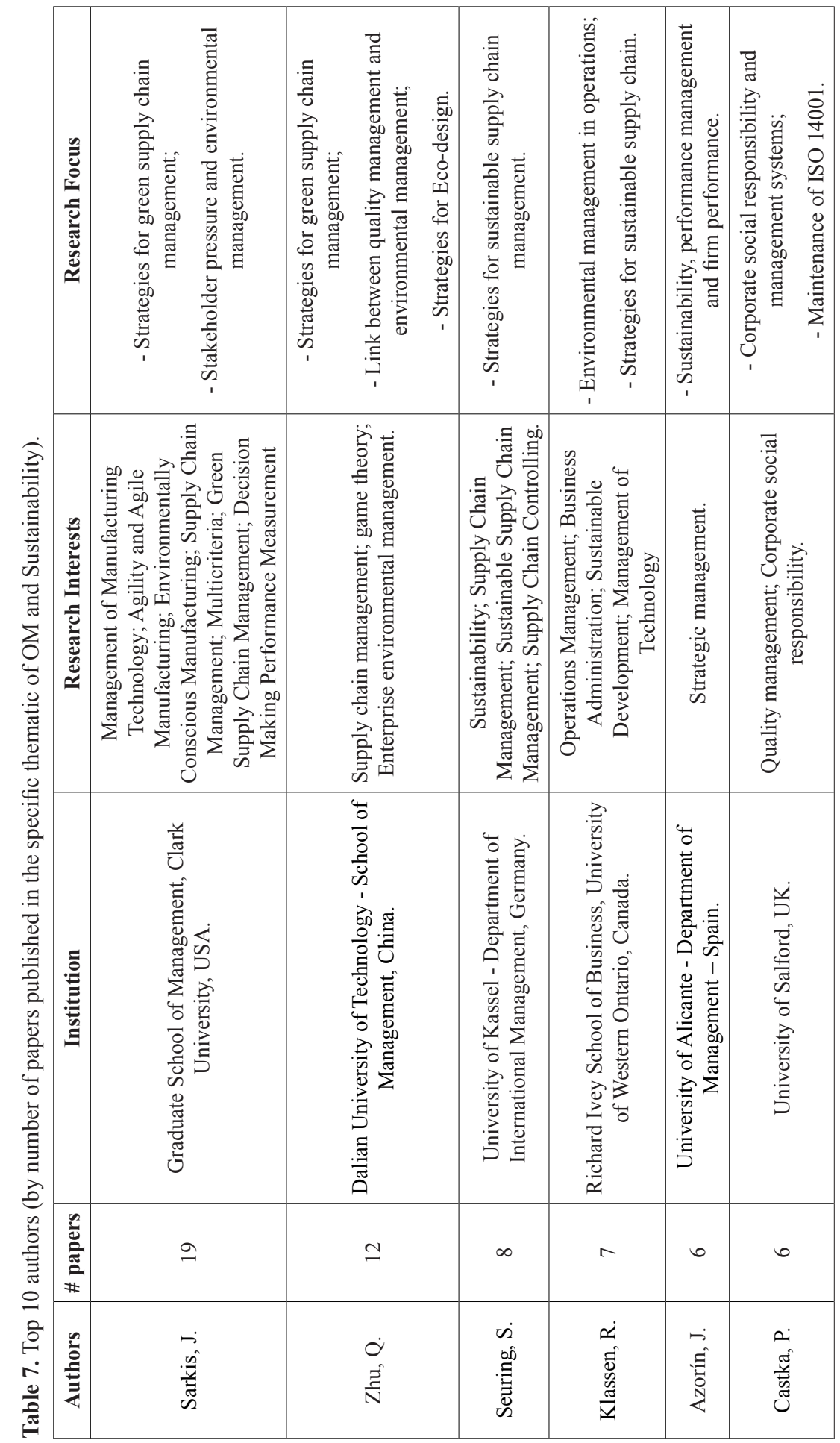




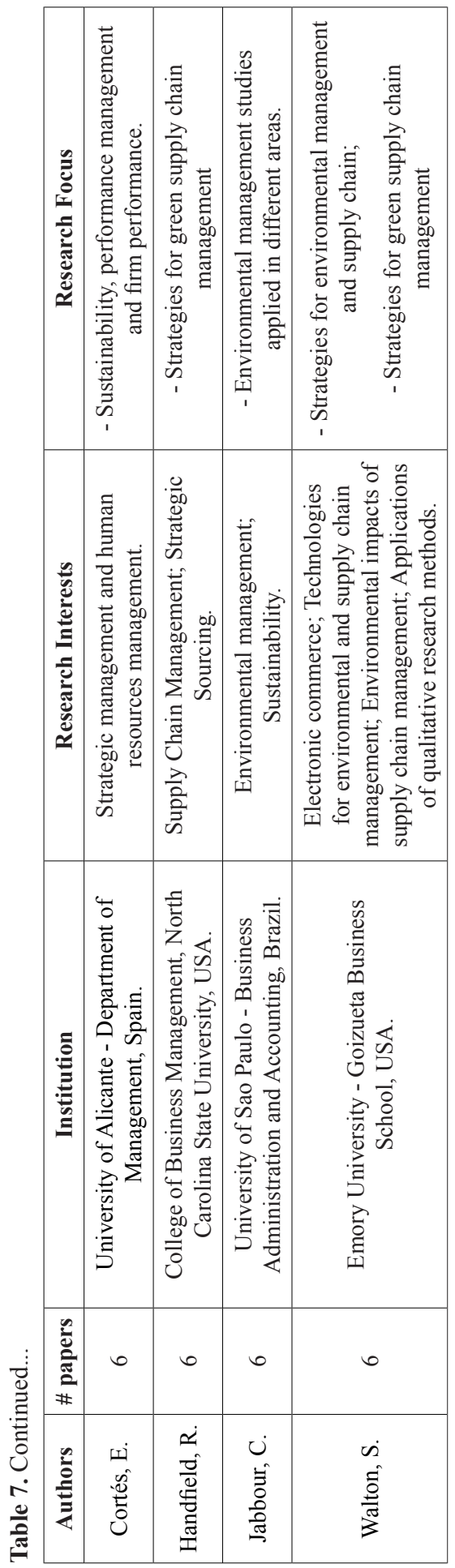


Table 8. Correlation test for centrality and productivity measures.

\begin{tabular}{|c|c|c|c|c|c|c|c|}
\hline \multicolumn{8}{|c|}{ Correlations } \\
\hline & & & Productivity & Degree & Closeness & Effsize & Betweenness \\
\hline \multirow{15}{*}{$\begin{array}{c}\text { Spearman's } \\
\text { rho }\end{array}$} & \multirow{3}{*}{ Productivity } & $\begin{array}{l}\text { Correlation } \\
\text { Coefficient }\end{array}$ & & & & & \\
\hline & & Sig. (2-tailed) & . & .000 & .001 & & \\
\hline & & $\mathrm{N}$ & 47 & 47 & 47 & 47 & 47 \\
\hline & \multirow{3}{*}{ Degree } & $\begin{array}{l}\text { Correlation } \\
\text { Coefficient }\end{array}$ & $.501^{* *}$ & & $.997 * *$ & $.955^{* *}$ & $.846^{* *}$ \\
\hline & & Sig. (2-tailed) & .000 & . & .000 & .000 & .000 \\
\hline & & $\mathrm{N}$ & 47 & 47 & 47 & 47 & 47 \\
\hline & \multirow{3}{*}{ Closeness } & $\begin{array}{l}\text { Correlation } \\
\text { Coefficient }\end{array}$ & $.485^{* *}$ & $.997 * *$ & & $.944 * *$ & $.835^{* *}$ \\
\hline & & Sig. (2-tailed) & .001 & .000 & . & .000 & .000 \\
\hline & & $\mathrm{N}$ & 47 & 47 & 47 & 47 & 47 \\
\hline & \multirow{3}{*}{ Effsize } & $\begin{array}{l}\text { Correlation } \\
\text { Coefficient }\end{array}$ & $.522 * *$ & $.955^{* *}$ & $.944 * *$ & & $.915^{* *}$ \\
\hline & & Sig. (2-tailed) & .000 & .000 & .000 & . & .000 \\
\hline & & $\mathrm{N}$ & 47 & 47 & 47 & 47 & 47 \\
\hline & \multirow{3}{*}{ Betweenness } & $\begin{array}{l}\text { Correlation } \\
\text { Coefficient }\end{array}$ & $.483 * *$ & $.846 * *$ & $.835 * *$ & $.915^{* *}$ & \\
\hline & & Sig. (2-tailed) & .001 & .000 & .000 & .000 & . \\
\hline & & $\mathrm{N}$ & 47 & 47 & 47 & 47 & 47 \\
\hline
\end{tabular}

**. Correlation is significant at the 0.01 level (2-tailed).

measures, demonstrating that, in general, the privileged position in the network contributes to the author's productivity (H1). The differences among core-periphery network variables also confirm that the central authors, by means of their relationships, can obtain more advantages than the peripheral authors, that is, authors located in the network core end up having a scientific productivity through co-authorships and their work is more recognized. Also, there is a higher probability of contributing to the field work $(\mathrm{H} 2)$, in addition to having more access to new ideas, according to the structural hole concept (H3).

With this, the central authors present significant results in measures considered relevant for this study. It is possible to see a greater number of connections and influence in the network (degree) and they are being considered like 'reference points' (closeness), represented by citations. These central group of authors has a structurally more favored position connecting other authors, being more cited and also sought to partnerships (betweenness), besides being in a better position to create new concepts and theories, because they have access to diverse information flows (effsize).

Comparing the analysis of keywords with the research focus of the main authors found in the network, it appears clearly as the group interests direct studies and establish the relationship with other authors. 
Table 9. Mann-Whitney Test: network core-periphery (ranking).

\begin{tabular}{|c|c|c|c|c|}
\hline \multirow{2}{*}{ Degree } & partition & $\mathbf{N}$ & Mean Rank & Sum of Ranks \\
\hline & $\mathbf{1}$ & $\mathbf{1 9}$ & $\mathbf{3 5 . 4 2}$ & 673.00 \\
\cline { 2 - 5 } & $\mathbf{2}$ & $\mathbf{2 8}$ & $\mathbf{1 6 . 2 5}$ & 455.00 \\
\cline { 2 - 5 } & Total & 47 & & \\
\hline \multirow{3}{*}{ Closeness } & $\mathbf{1}$ & $\mathbf{1 9}$ & $\mathbf{3 5 . 4 2}$ & 673.00 \\
\cline { 2 - 5 } & $\mathbf{2}$ & $\mathbf{2 8}$ & $\mathbf{1 6 . 2 5}$ & 455.00 \\
\hline \multirow{3}{*}{ Effsize } & Total & 47 & & \\
\cline { 2 - 5 } & $\mathbf{1}$ & $\mathbf{1 9}$ & $\mathbf{3 3 . 4 7}$ & 636.00 \\
\cline { 2 - 5 } & $\mathbf{2}$ & $\mathbf{2 8}$ & $\mathbf{1 7 . 5 7}$ & 492.00 \\
\hline \multirow{3}{*}{ Betweenness } & $\mathbf{1}$ & $\mathbf{1 9}$ & & 620.00 \\
\cline { 2 - 5 } & $\mathbf{2}$ & $\mathbf{2 8}$ & $\mathbf{1 8 . 1 4}$ & 508.00 \\
\cline { 2 - 5 } & Total & 47 & & 579.00 \\
\hline \multirow{3}{*}{ Productivity } & $\mathbf{1}$ & $\mathbf{1 9}$ & $\mathbf{3 0 . 4 7}$ & 549.00 \\
\cline { 2 - 5 } & $\mathbf{2}$ & $\mathbf{2 8}$ & $\mathbf{1 9 . 6 1}$ & \\
\hline
\end{tabular}

Table 10. Significance values in the centrality measures between network core and periphery.

\begin{tabular}{|c|c|c|c|c|c|}
\hline \multicolumn{7}{|c|}{ Test Statistics $^{\mathrm{a}}$} \\
\hline & Degree & Closeness & Effsize & Betweenness & Productivity \\
\hline Mann-Whitney U & 49.000 & 49.000 & 86.000 & 102.000 & 143.000 \\
\hline Wilcoxon W & 455.000 & 455.000 & 492.000 & 508.000 & 549.000 \\
\hline Z & -4.710 & -4.708 & -3.902 & -3.555 & -2.874 \\
\hline Asymp. Sig. (2-tailed) & $\mathbf{. 0 0 0 *}$ & $\mathbf{. 0 0 0 *}$ & $\mathbf{. 0 0 0 *}$ & $\mathbf{. 0 0 0 *}$ & $\mathbf{. 0 0 4 *}$ \\
\hline
\end{tabular}

${ }^{a}$ Grouping Variable: partition. ${ }^{*} \mathrm{p}<0.05$ - statistically significant difference.

In this sense, it appears that the key issues for sustainability studies in OM are: supply chain management, green supply chain management, environmental management and corporate social responsibility.Sustainability as a keyword has been quoted more frequently together with "supply chain management (SCM)", whereas SCM is strongly related to the topic of "corporate social responsibility" (CSR). The CSR concept is guided by the dimensions of (environmental, social and economic) sustainability, and the connection of these words with the SCM represents a significant trend of applying sustainability concepts, in an integrated way, throughout the chain.

\section{Conclusion}

The evolution in the number of studies in areas regarded as relevant to the $\mathrm{OM}$ also points out that the field has the tendency to research more strategic 
and contemporary issues to the organizations. Such factors have contributed to the establishment of the OM as a discipline.

The results indicate Joseph Sarkis as the most central author in the network and his studies on green supply chain management and environmental management have been identified as relevant by the community, visualized by the partnerships and citations.

The results also point out Brazil as an party in the study evolution, occupying a prominent position among authors and among institutions. However, it appears that such participation could be more representative if the Brazilian community had strengthened its network with international authors, promoting more multinational partnerships.

According to its main purpose, this paper presents information that contributes to the OM field development. The evolution of topics demonstrates that the OM fields walk according to the predictions of previous studies to more macros and strategic issues, and the inclusion of sustainability reflects that. The results provide some directions for research topics involving studies on the OM integrating the three dimensions of sustainability - not only the environmental dimension -, the expansion of bibliometric analyses (including multivariate data), the relations among authors and possibly formed clusters and create subsidies that encourage more Brazilian researchers to lean over the theme.

Due to the limitations presented and field amplitude, further research will be important to map the field, such as the study replication with larger samples and the application of other multivariate data analysis method for refining the results.

\section{References}

Almeida, F. (2007) The challenges of sustainability (in portuguese: Os desafios da sustentabilidade). Rio de Janeiro: Elsevier.

Bayraktar, E.; Jothishankar, M.C.; Tatoglu, E. and Wu, T. (2007) Evolution of operations management: past, present and future. Management Research News, Vol. 30, No. 11, pp. 843-71. http://dx.doi.org/10.1108/01409170710832278

Burt, S.R. (1992) Structural holes: the social structure of competition. Cambridge. London: Harvard University.

Carter, C.R. and Rogers, D.S. (2008) A framework of sustainable supply chain management: moving toward new theory. International Journal of Physical Distribution \& Logistics Management, Vol. 38, No. 5, pp. 360-387. http://dx.doi.org/10.1108/09600030810882816

Chuang, K.-Y.; Huang, Y.-L. and Ho, Y.-S. (2007) A bibliometric and citation analysis of stroke-related research in Taiwan. Scientometrics, Vol. 72, No. 2, pp. 201-212. http://dx.doi. org/10.1007/s11192-007-1721-0

Elkington, J. (1997) Cannibals with forks: the triple bottom line of 21st century business. Oxford: Capstone.

Field, A. (2009) Discovering Statistics Using SPSS (in portuguese: Descobrindo a Estatística Usando o SPSS). 2. ed. Porto Alegre: Bookman.

Garfield, E. (1997) Citation indexing - Its theory and application in science. Philadelphia: Technology and Humanitied, Institute of Scientific Information - ISI Press. 
Glänzel, W. (2001) An introduction to principle differences between citations and sitation links. A methodological and mathematical approach. In: 6th Nordic Workshop on Bibliometric. Available: http://www.umu.se/inforsk/6thNordicBibliometric.htm. Access: 10th July 2011.

Gold, S.; Seuring, S. and Beske, P. (2010) Sustainable supply chain management and inter-organizational resources: a literature review.Corporate Social Responsibility and Environmental Management, Vol. 17, No. 4, pp. 230-245.

Gupta, M. (1995) Environmental management and its impactontheoperationsfunction. International Journal of Operations \& Production Management, Vol. 15, No. 8, pp. 34-51. http:// dx.doi.org/10.1108/01443579510094071

Hanneman, R.A. and Riddle, M. (2011) Introduction to social network methods. Riverside: University of California. Available: http://faculty.ucr.edu/ hanneman/.

Hart, S. (2005) Capitalism in the crossroads. Philadelphia:Wharton School Publishing Co.

Hart, S.L. (1995) A natural resource based view of the firm. The Academy of Management Review, Vol. 20, No. 4, pp. 986-1014.

Hayes, R.H and Wheelwright, S.C. (1984) Restoring our competitive edge: competing throught manufacturing. New York: John Wiley.

Hutchins, M. and Sutherland, J. (2008) An exploration of measures of social sustainability and their application to supply chain decisions. Journal of Cleaner Production, Vol. 16, No. 15, pp. 1688-1698. http://dx.doi.org/10.1016/j.jclepro.2008.06.001

Kleinberg, J.; Suri, S.; Tardos, E. and Wexler, T. (2008) Strategic network formationwithstructuralholes. ACM SIGecom Exchanges, Vol. 7, No. 3, pp. 1-4. http://dx.doi. org/10.1145/1486877.1486888

Kleindorfer, P.R.; Singhal, K. and Van Wassenhove, L.N. (2005) Sustainable Operations Management. Production and Operations Management, Vol. 14, No. 4, pp. 482-492. http://dx.doi.org/10.1111/j.1937-5956.2005.tb00235.x

Leidesdorff, L. (2007) Scientific communication and cognitive codification: social systems theory and the sociology os scientific knowledge. European Journal of Social Theory, Vol. 10, No. 3, pp. 1-22.

Machado-da-Silva, C.L.; Guarido Filho, E.R. and Rossoni, L. (2006) Organizational fields and the structuration perspective: analytical possibilities. Revista de Administração Contemporânea, Vol.10, Special Edition, pp. 159-196. (In portuguese)

McIntire, J.S. (2006) The clothing and textile research base: an author cocitation study. Dissertation. Faculty of the Graduate School, University of Missouri.

Mendeley Supporting Team. (2011) Getting Started with Mendeley. London: Mendeley Ltd., pp. 1-14. Available: www.mendeley.com.

Pilkington, A. and Fitzgerald, R. (2006) Operations management themes, concepts and relationships: a forward retrospective of the IJOPM. International Journal of Operations and Production Management, Vol. 11, pp. 1255-1275. http://dx.doi.org/10.1108/01443570610705854

Pilkington, A. and Liston-Heyes, C. (1999) Is production and operations management a discipline? A citation/co-citation study. International Journal of Operations and Production Management, Vol. 19, pp. 7-20. http://dx.doi.org/10.1108/01443579910244188

Pilkington, A. and Meredith, J. (2009) The evolution of the intellectual structure of operations management -1980-2006: a citation/co-citation analysis. Journal of Operations Management, Vol. 27, pp. 185-202. http://dx.doi.org/10.1016/j.jom.2008.08.001

Pinheiro de Lima, E.; Gouvea da Costa, S.E.; Oliveira Neto, S.C. and Cavenaghi, V. (2008) Desenvolvimento de um marco conceitual para a gestão estratégica de operações baseada 
em princípios de responsabilidade social corporativa, in: Oliveira, V.F.; Cavenaghi, V. and Másculo, F.S. (Org.), Tópicos emergentes e desafios metodológicos em engenharia de produção: casos, experiências e proposições. v II. Rio de Janeiro: ABEPRO, pp. 266-277.

Pinheiro, L. V. and Silva, E. L. (2008) The cognitive networks in information science in Brazil: a study in scientific papers published in journals (in portuguese): As redes cognitivas na ciência da informação brasileira: um estudo nos artigos científicos publicados nos periódicos da área). Ciência da Informação, Vol. 37, No. 3, pp. 38-50. http://dx.doi.org/10.1590/S010019652008000300003

Pitelis, C.N. and Vasilaros, V. (2010) The determinants of value and wealth creation at the firm, industry, and national levels: A conceptual framework and evidence. Journal Contributions to Political Economy, Vol. 29, No. 1, pp. 33-58. http://dx.doi.org/10.1093/cpe/ bzq003

Platts, K.W. (2007) Strategies for sustainable manufactuting, in: International Conference o Industrial Engineering and Operations Management- ICIEOM 2007, Plenary Lecturer, Foz do Iguazu, Brazil.

Porter, M.E. and Kramer, M.R. (2006) The link between competitive advantage and corporate social responsibility”. Harvard Business Review, Vol. 84, No. 12, pp. 1-14.

Porter, M.E. and Van der Linde, C. (1995) Green and Competitive: Ending the Stalemate. Harvard Business Review, Vol. 73, No. 5, pp. 120-134, Sep-Oct.

Powell, W.W.; White, D.R.; Koput K.W. and Owen-Smith, J. (2005) Network Dynamics and Field Evolution: The Growth of Interorganizational Collaboration in the Life Sciences. American Journal of Sociology,Vol. 110, No. 4, pp. 1132-1205. http://dx.doi. $\operatorname{org} / 10.1086 / 421508$

Seliger, G. (2007) Sustainability in manufacturing, recovery of resources in product and material cycles. Springer: New York. http://dx.doi.org/10.1007/978-3-540-49871-1

Sengupta, J.N. (1992) Bibliometrics, infometrics, scientometrics and librametrics: an overview. International Journal of Libraries and Information Systems, Vol. 42, No. 2, pp. 75-98.

Seuring, S. and Muller, M. (2008) From a literature review to a conceptual framework for sustainable supply chain management. Journal of Cleaner Production, Vol. 16, No. 15, pp. 1699-1710. http://dx.doi.org/10.1016/j.jclepro.2008.04.020

Skinner, W. (1969) Manufacturing: the missing link in corporate strategy. Harvard Business Review: Boston. May-June.

Skinner, W. (1974) The focused factory. Harvard Business Review, pp. 136-45,

Slack, N. (2005) Operations strategy: will it ever realize its potential? Gestão \& Produção, Vol. 12 No. 3, pp. 323-332. http://dx.doi.org/10.1590/S0104-530X2005000300004

Sower, V.; Motwani, J. and Savoie, M. (1997) Classics in production and operations management. International Journal of Operations \& Production Management,Vol. 17, No. 1, pp. 15-28. http://dx.doi.org/10.1108/01443579710157961

Sprague, L. (2007) Evolution of the field of operations management. Journal of Operations Management,Vol. 25, pp. 219-238. http://dx.doi.org/10.1016/j.jom.2007.01.001

Talbot, J. and Venkataraman, R. (2011) Integration of sustainability principles into project baselines using a comprehensive indicator set. International Business \& Economics Research Journal, Vol. 10, No. 9, pp. 29-40.

Taylor, A. and Taylor, M. (2009) Operations management research: contemporary themes, trends and potential future directions. International Journal of Operations \& Production Management, Vol. 29, No. 12, pp. 1316-1340. http://dx.doi.org/10.1108/01443570911006018 
Ueda, K.; Takenaka, T.; Váncza, J. and Monostorim, L. (2009) Value creation and decision-making in sustainable society. CIRP Annals - Manufacturing Technology, Vol. 58, No. 2, pp. 681-700.

Van Bommel, H.W.M. (2011) A conceptual framework for analyzing sustainability strategies in industrial supply networks from an innovation perspective. Journal of Cleaner Production, Vol. 19, No. 8, pp. 895-904. http://dx.doi.org/10.1016/j.jclepro.2010.12.015

World Commission on Environment and Development - WCED. (1987) Our Common Future. Oxford: Oxford University Press.

Westkamper, E. Alting, L. and Arndt, G. (2000) Life Cycle Management and Assessment: Approaches and Visions Towards Sustainable Manufacturing (keynote paper). CIRP Annals - Manufacturing Technology, Vol. 49, No. 2, pp. 501-526.

White, D.R.; Owen-Smith, J. Moody, J. and Powel, W.W. (2004) Networks. Fields and Organizations: Micro-Dynamics, Scale and Cohesive Embeddings. Computational \& Mathematical Organization Theory, Vol. 10, pp. 95-117. http://dx.doi.org/10.1023/ B:CMOT.0000032581.34436.7b

Wilkinson, A.; Hill, M. and Gollan, P. (2001) The sustainability debate. International Journal of Operations \& Production Management, Vol. 2, No. 2, pp. 1492-1502. http://dx.doi. org/10.1108/01443570110410865

\section{Biography}

Carla Gonçalves Machado is a researcher of the Industrial and Systems Engineering Graduated Program of Pontifical Catholic University of Paraná - PUCPR. She holds a BSc Degree in Social Communication - Public Relations (UNESP - Brazil) and a MSc Degree in Production Engineering (UNESP - Brazil). Her research and teaching is in sustainable operations, supply chain management, operations strategy and performance measurement.

Contact: carla.goncalves@pucpr.br

Pamela Mocelin Manfrim is a researcher of the Industrial and Systems Engineering Graduated Program of Pontifical Catholic University of Paraná - PUCPR. She holds a BSc Degree in Production Engineering (PUCPR - Brazil) and a MSc Degree in Industrial and Systems Engineering (PUCPR - Brazil). Her research and teaching is in sustainable operations, facilities design, operations strategy and performance measurement.

\section{Contact:pamela@apetit.com.br}

Dr. Edson Pinheiro de Lima is a Full Professor (Technology Management) at the Industrial and Systems Engineering Graduate Program at the Pontifical Catholic University of Parana (PUCPR), and an Associate Professor at the Federal University of Technology - Parana (UTFPR), both in Brazil. He was from 2009-2010 the Program Director of the Industrial and Systems Engineering Graduate Program at PUCPR. On 2007, he spent one year as a Visiting Academic at the Operations Management Group of the Warwick Business School, UK. He holds a BSc Degree in Electrical Engineering (UTFPR- Brazil), a MSc Degree in Electrical Engineering - Automation (UNICAMP - Brazil) and a PhD in Industrial Engineering (UFSC - Brazil). His research and teaching is in operations strategy, performance management, strategic management, organisational design and sustainable operations.

Contact: e.pinheiro@pucpr.br 
Dr. Sergio E. Gouvea da Costa is a Full Professor (Operations Management) at the Industrial and Systems Engineering Graduate Program at the Pontifical Catholic University of Parana (PUCPR), and an Associate Professor at the Federal University of Technology - Parana (UTFPR), both in Brazil. He is a Board Member of the International Foundation for Production Research (IFPR) and a Board Member of the Society for Engineering and Management Systems of the Institute of Industrial Engineers (SEMS/ IIE). He spent one year as a Visiting Professor at the Edward P. Fitts Department of Industrial and Systems Engineering of the North Carolina State University, USA (2009-2010). He holds a BSc Degree in Electrical Engineering (UTFPR - Brazil), a MSc Degree in Electrical Engineering - Automation (UNICAMP - Brazil) and a PhD in Industrial Engineering (USP - Brazil). His research and teaching is in manufacturing strategy and performance area, maintenance management, AMT adoption, lean and sustainable operations.

Contact: s.gouvea@pucpr.br

\section{Article Info:}

Received: August, 2012

Accepted: October, 2012 